\title{
Croatian Preschool Teachers' Self-Perceived Competence in Managing the Challenging Behaviour of Children
}

Kathleen Beaudoin ${ }^{1}$, Sanja Skočić Mihić ${ }^{\star 2}$ AND Darko LonČarić ${ }^{3}$

$\approx$ Managing behaviour is a complex component of the teaching process and one that teachers consistently identify as an area of great concern. This study aimed to examine teachers' perceptions regarding their competence for managing the challenging behaviour of young children and to identify the factors that affect these beliefs. A total of 204 preschool teachers working in Kindergarten Rijeka, Croatia participated. Teachers completed an exploratory survey of self-perceptions of competence in managing the challenging behaviours encountered in their classrooms. Factor analysis revealed a one-factor structure for self-perceived competence, and all scales showed good psychometric properties. Preschool teachers' assessment of their own competence in managing challenging behaviour was explained by the level of support they received from other professionals when faced with children's challenging behaviour and prior coursework in classroom management. Participants with higher levels of professional support and more coursework in classroom management estimated themselves to be more competent in managing challenging behaviour. The results suggest that Croatian preschool teachers need training in classroom management and greater access to professional support personnel when working with students with challenging behaviours.

Keywords: classroom management, preschool teachers, self-perceived competence, behaviour management

1 University of Washington Tacoma, USA.

$2{ }^{\star}$ Corresponding Author. University of Rijeka, Faculty of Teacher Education, Croatia; sskocicmihic@gmail.com.

3 University of Rijeka, Faculty of Teacher Education, Croatia. 


\section{Samoocena kompetentnosti hrvaških vzgojiteljev za spoprijem $\mathrm{z}$ neželenim vedenjem otrok}

Kathleen Beaudoin, Sanja Skočić Mihić in Darko LonČarić

$\sim$ Obvladovanje vedenja je kompleksna komponenta procesa poučevanja in eno izmed področij, ki ga vzgojitelji označujejo kot enega izmed področij skrbi. Namen raziskave je bil ugotoviti, kako vzgojitelji samoocenjujejo svoje kompetence pri obvladovanju neželenega vedenja predšolskih otrok, in ugotoviti dejavnike, ki vplivajo na ta prepričanja. V okviru raziskave so sodelovali 204 vzgojitelji iz Vrtca Reka, Hrvaška. Vzgojitelji so izpolnili vprašalnik o samooceni njihovih kompetenc pri obvladovanju neželenega vedenja, ki so ga zaznali v svoji vrtčevski skupini. Faktorska analiza je pokazala enofaktorsko strukturo za samooceno kompetenc, pri čemer so lestvice pokazale dobre psihometrične značilnosti. Ocena vzgojiteljev glede lastnih kompetenc pri obvladovanju neželenega vedenja otrok je pojasnjena $\mathrm{z}$ ravnjo podpore, ki jo dobijo od drugih strokovnjakov, ko so soočeni $\mathrm{z}$ neželenim vedenjem, in s predhodnim delom pri vodenju skupine. Udeleženci $\mathrm{z}$ višjo ravnjo strokovne podpore in več predhodnega dela pri vodenju skupine so se samoocenili kot kompetentnejši pri obvladovanju neželenega vedenja otrok. Rezultati kažejo, da hrvaški vzgojitelji potrebujejo usposabljanja za vodenje razreda/skupine in večji dostop do strokovnega podpornega osebja, ko delajo $\mathrm{z}$ učenci $\mathrm{z}$ neželenimi vedenji.

Ključne besede: vodenje razreda, vzgojitelji, samoocena kompetenc, obvladovanje vedenja 


\section{Introduction}

A critical feature in the effective functioning of a classroom is the ability of the teacher to efficiently manage student behaviour. This management includes the efforts that teachers take to prevent the occurrence of problem behaviour as well as how they respond to and intervene once problem behaviour has occurred. As such, classroom management makes for a complex component of the teaching process. It is little wonder that teachers new to the profession consistently identify classroom management as an area of great concern (Fontaine, Kane, Duquette, \& Savoie-Zajc, 2012; Veenman, 1984). However, even though experience generally improves confidence in one's ability to manage the classroom (e.g., Choy, Chong, Wong, \& Wong, 2011; Kotaman, 2010), classroom management remains a front-running concern for experienced teachers (Chan, 2008; Fontaine et al., 2012; Ingersoll, 2001; Melnick \& Meister, 2008; Wong, Chong, \& Choy, 2012). Furthermore, a teacher's ability to address challenging behaviour can play a critical role in how that teacher is assessed by others. Teacher evaluation procedures commonly include classroom management as a criterion for proficient teaching performance (e.g., Marzano \& Toth, 2013) because efficient behaviour management sets the stage for increased learning to occur (Wang, Haertel, \& Walberg, 1994). Thus, it is not surprising that school administrators frequently identify lack of skill in classroom management as a cause of teacher ineffectiveness (e.g., Range, Duncan, \& Scherz, 2012; Torff \& Sessions, 2005).

Although the ability to manage a classroom is arguably a requirement for successful teaching, many teachers enter the profession with little to no formal training in classroom management. The paucity of related coursework in teacher preparation programmes appears to be widespread. For example, Stough (2006) found that in the United States approximately only 30\% of teacher preparation programmes included coursework that specifically identified classroom management in their titles. Alvarez's (2007) research presented a similar pattern among elementary and middle school teachers in Virginia. She found that $64.5 \%$ of her sample reported no prior specialised training in classroom management and only $12.1 \%$ reported their training coming from coursework in classroom management. Wubbles (2011) also noted limited course offerings within teacher preparation programmes in Australia, Germany and the Netherlands. Johansen, Little, and Akin-Little (2011) reported a similar trend for programmes in New Zealand. For the purposes of this project, we conducted an informal investigation of teacher preparation programmes in Croatian universities and found similar results. The majority of university programmes 
throughout the country had no required classroom management courses listed within their teacher education programmes.

A lack of preparation for developing the skills to manage a classroom can set the stage for increased levels of acting out behaviour; however, even well prepared and experienced teachers may face classrooms with high numbers of students with significant behavioural issues. In the United States, preschool and kindergarten teachers are highly likely to encounter students with challenging behaviours in their classrooms. Studies have indicated that, upon entrance to school, a range of 10 to $25 \%$ of young children display significant levels of behavioural problems (Campbell, 1995; Lavigne et al., 1996; Qu \& Kaiser, 2003; West, Denton, \& Germino-Hausken, 200o). Facing high levels of behaviour problems may also undermine a teacher's confidence in their ability to manage the classroom environment. Specifically, researchers have found that teachers with higher levels of concern about student misbehaviour report lower levels of confidence in their ability to manage behaviour (Arbuckle \& Little, 2004; Martin, Linfoot, \& Stephenson, 1999; Stephenson, Linfoot, \& Martin, 2000). Early childhood educators' perceptions of behaviour problems also have been associated with higher levels of job stress (Friedman-Krauss, Raver, Neuspiel, \& Kinsel, 2014). On a positive note, professional development opportunities have been used to improve management practices, leading to greater self-confidence. In one study, Shernoff and Kratochwill (2007) found that by providing training instruction in a research-based classroom management programme (i.e., The Incredible Years Teacher Classroom Management Program; WebsterStratton, 2006), teacher self-confidence in their ability to manage the classroom increased. Furthermore, Carlson, Tiret, Bender, and Benson (2011) found that similar training in this programme led to increased use of positive management strategies by the teachers as well as teachers' improved perceptions of the usefulness of the strategies.

Teachers who possess both skill and self-confidence in classroom management remain likely to need additional support for managing children with challenging behaviour. The work of Martin et al. (1999) suggested that teachers access support in direct response to the challenging behaviours they encounter. Martin et al. examined the type and frequency of supports accessed by teachers in the early grades and found an overwhelming preference for gaining support from adults within the school system (e.g., colleagues, parents, counsellors, administrators) rather than from outside of school resources. Specifically, the preferred methods of support were noted as being school-based in-service courses and support from behaviour specialists. However, it should be noted that these researchers did not find that preferences translated into actual use of services. 
They posited the lack of use of support from behaviour specialists might stem from a lack of available personnel with this expertise.

While research on classroom management is accruing in many areas of the world, relatively little is known about the nature of student behaviour in Croatian classrooms, nor the views held by Croatian teachers regarding their abilities to address the student behaviours they encounter in school settings. The scant research that does exist suggests that Croatian elementary school teachers view emotional and behavioural problems as low-level problems within their classrooms (Keresteš, 2006; Vidić, 2010). Nevertheless, recent research indicates that Croatian preschool and elementary teachers do encounter students with challenging behaviours (Beaudoin, Lončarić, \& Skočić Mihić, 2017; Beaudoin, Skočić Mihić, \& Lončarić, 2016a, 2016b). However, what this research does not indicate is how Croatian preschool teachers view their own competence to address challenging behaviours. In addition, what can be assumed from the current requirements of teacher preparation programmes across Croatian universities is that it is relatively commonplace for educators to enter the profession of teaching with little or no coursework in classroom management.

It is well established that the practice of early intervention to address behaviour problems is the most efficacious for positive long-term outcomes for students. There is ample opportunity in preschool settings for 'classroom management' in the form of managing the behaviours of young children and addressing problem behaviours in the early stages of development. Sak, Sahin Sak, and Yerlikaya (2015) described the role of the early childhood educator as "organizers of the physical environment, planners of instructional activities, and managers of classroom relationships and behaviors" (p. 329). Thus, early childhood educators are essential candidates for increased training in classroom management and for receipt of support for addressing the challenging behaviour of their students. In an effort to provide meaningful and targeted professional development to one group of preschool educators not likely to have had extensive prior coursework in this area, we set out to examine the nature of challenging behaviours commonly encountered in Croatian preschool classrooms. Moreover, we were interested in understanding how preschool teachers viewed their own competence for managing these challenging behaviours. Thus, the focus of the present investigation is twofold. First, we present the results of an examination of an exploratory survey used to determine preschool teachers' perceptions about their own competence for addressing the management challenges that they face in their classrooms. Second, we investigate the potential influence of factors related to experience, education, and access to 
professional support on the perceptions preschool teachers hold regarding their competence in managing challenging behaviour in their classrooms.

\section{Method}

\section{Participants}

In total, 300 preschool teachers from urban preschools in Rijeka, Croatia were recruited to participate in the present study. Of these, 204 preschool teachers completed surveys resulting in a return rate of $68 \%$. Gender was reported for $97 \%$ of the participants ( 1 male and 196 female). The average age of participants was identified as 43 years old $(S D=8.64)$, with an average of 20 years $(S D=9.84)$ of teaching experience and a class size of 21.06 children $(S D=$ 4.71). Seventy-four per cent reported having had prior experience working with children with challenging behaviour, $16 \%$ reported no prior experience in this area and 10\% did not respond to this question. With regard to prior coursework in classroom management, $7 \%$ of the 198 preschool teachers responding to the question reported having had any prior coursework in this area.

\section{Measures}

The exploratory survey used in this study assessed preschool teachers' perceptions of the frequency and type of challenging behaviours (i.e., internalising, externalising) exhibited in their classrooms, the level of professional support received for working with these children, and self-perceived competence for managing challenging behaviours. Demographic information and prior experience related to behaviour management were also collected. Preschool teachers reported the frequency of challenging behaviours observed in their classrooms using a five-point scale ranging from 1 (never) to 5 (always). The subscale for internalising behaviour problems ( 3 items) included items such as difficulty maintaining attention to task and difficulty engaging in shared play. The 11-item subscale for externalising behaviour problems included behaviours such as physical and verbal aggression towards peers, blaming others, and disturbing others' work. The internalising and externalising subscales demonstrated adequate internal consistency as measured by Cronbach's alpha coefficient ( $\alpha=0.81$ and $\alpha=0.88$, respectively). ${ }^{4}$

Participants indicated the level of professional support (e.g., psychologist, educator, pedagogue, speech therapist, specialist in rehabilitation) that they received for working with students with challenging behaviour on a four-point

4 Additional information on psychometric characteristics is available from the authors upon request. 
scale ranging from 1 (no support) to 4 (full support). Participants responded as follows: $7 \%$ reported receiving full support, $37 \%$ reported receiving some professional support, $24 \%$ reported receiving little support, and $18 \%$ reported no support. Fifteen percent of participants did not respond to this question.

Preschool teachers' self-perceived competence in working with children with challenging behaviours was assessed through six items where participants responded on a five-point Likert-type scale from 1 (I don't feel competent) to 5 (I feel completely competent). This subscale included items related to overall classroom management, prevention and intervention with problem behaviours, and ability to collaborate with other professionals and parents for behaviour related purposes. Psychometric properties for this scale are presented in the results section of this paper.

\section{Procedure}

Initial approval for participation was obtained from the administrative director overseeing all public preschools in the city. Following this, schoolbased leaders overseeing preschools in each of five regions of DV Rijeka provided additional approval and support for participation of teachers within their schools. Professional staff (i.e., lead school psychologist assigned to each region) also met with preschool teachers from each school to explain the purpose of the research and to distribute the questionnaires. Preschool teachers were given approximately one week to complete and return the anonymous surveys to professional staff.

\section{Results}

\section{Frequency of challenging behaviour}

Preschool teacher ratings of the frequency of internalising behaviours observed in their classrooms ranged from an item mean of $3.03(\mathrm{SD}=1.15)$ to $3.19(\mathrm{SD}=.99)$, with an overall mean of $3.07(\mathrm{SD}=.90)$. Preschool teacher ratings of the frequency of externalising behaviours observed in their classrooms ranged from an item mean of $1.69(\mathrm{SD}=.92)$ to $3.47(\mathrm{SD}=.68)$, with an overall mean of $2.86(\mathrm{SD}=.68) .^{5}$

\section{Preschool teachers' self-perceived competence in behaviour management: Descriptive statistics}

The response format of the Preschool Teachers' Self-Perceived Competence in Behaviour Management subscale ranged from 1 (I don't feel competent) to 5 (I

5 For a detailed presentation of the item results, see Beaudoin et al. (2016b). 
feel fully competent) on each item of the scale. The mean responses of the six items ranged from 3.58 to 3.82 , indicating little variance between items (see Table 1).

Table 1

Descriptive Statistics of the Self-Perceived Competence Scale

\begin{tabular}{lccccc}
\hline \multicolumn{1}{c}{ Descriptive Statistics } & & & & & \\
\hline Competence & N & Min & Max & M & SD \\
\hline 1. Working with children with challenging behaviours & 196 & 1.00 & 5.00 & 3.58 & .76 \\
2. Classroom management & 196 & 1.00 & 5.00 & 3.82 & .72 \\
3. Prevention of challenging behaviours & 196 & 1.00 & 5.00 & 3.62 & .91 \\
4. Implementing interventions to reduce challenging behaviours & 194 & 1.00 & 5.00 & 3.59 & .95 \\
5. Collaboration with professional colleagues who work with & 194 & 1.00 & 5.00 & 3.63 & .93 \\
$\quad$ children with challenging behaviours & 195 & 1.00 & 5.00 & 3.66 & .86 \\
\hline 6. Collaborating with parents & & & & &
\end{tabular}

\section{Composite scale for preschool teachers' self-perceived competence in} behaviour management: Exploratory factor analysis

Exploratory factor analysis was used to determine the factor structure of the preschool teachers self-perceived competence scale. Factors were determined with the Maximum Likelihood factor extraction method and the Cattell scree test was used to determine the number of the significant factors. In order to obtain the simple factor structure, oblimin rotation was used. One factor solution was retained with the factor explaining $58.55 \%$ of variance (eigenvalues of the first three factors were: 3.92, 0.63, 0.47). As presented in Table 2, all were equal to or greater than 0.46 and loadings on the factor were equal to or greater than 0.68 . The mean of the composite score for perceived competence was 3.66 $(\mathrm{SD}=0.68)$. The scale demonstrated adequate reliability for the purposes of this research with a Cronbach's alpha coefficient of $\alpha=.89$ for the composite score.

Table 2

Factor analysis

\begin{tabular}{lcc}
\hline FACTOR self-perceived competence & $\mathrm{h}^{2}$ & 1 \\
\hline Implementation of interventions to reduce challenging behaviours & .72 & .85 \\
Prevention of challenging behaviours & .69 & .83 \\
Collaboration with professional colleagues who work with children with challenging behaviours & .58 & .75 \\
Working with children with challenging behaviours & .53 & .73 \\
Classroom management & .50 & .71 \\
Partnering/collaborating with parents & .46 & .68 \\
\hline
\end{tabular}




\section{Predicting preschool teachers' ratings of self-competence in managing challenging behaviour: Hierarchical regression}

Data were analysed using a Hierarchical Regression model to predict preschool teachers' levels of perceived competence regarding their ability to manage the challenging behaviour of students. In Step 1, Teacher's age and prior experience in working with children with challenging behaviour $(1,0 ; 1=$ had $e x-$ perience) were entered as predictors of self-perceived competence in classroom management. Neither variable contributed significantly to the prediction of selfperceived competence (i.e., $p=.05$ ). Preschool teacher's age and prior experience in managing challenging behaviour explained only $4 \%$ of the total variance.

In Step 2, preschool teacher's prior education in classroom management (1, o; 1 = had prior education), level of professional support received for working with children with challenging behaviour, and the frequency of types of behaviour encountered in the classroom (i.e., internalising and externalising behaviour) were examined to see if they predicted self-perceived competence over and above the variance explained by age and experience with challenging behaviour (i.e., $4 \%$ variance, $\left.R^{2}=0.04, F(2,98)=1.77, p>0.05\right)$. Entering those four variables accounted for an additional 15\% of the total variance of self-perceived competence. Contrary to predictions, neither externalising nor internalising behaviours reached statistical significance as predictor variables; however, preschool teacher's prior education in classroom management and self-reported level of support received from other professionals (e.g., psychologist, educator, pedagogue, speech therapist, specialist in rehabilitation) were significant predictors of higher self-perceived competence (i.e., 19\% variance, $R^{2}=0.19, F(6,94)=3.72, p<0.01$, see Table 3 .

Table 3

Summary of hierarchical regression analysis of predictors of estimated competence, $N=94$

\begin{tabular}{lcccccc}
\hline \multirow{2}{*}{ Predictor } & \multicolumn{3}{c}{ Model 1 } & \multicolumn{3}{c}{ Model 2 } \\
\cline { 2 - 7 } & $\mathrm{B}$ & SE B & $\beta$ & $\mathrm{B}$ & SE B & $\beta$ \\
\hline Age & .00 & .01 & .03 & .00 & .01 & .06 \\
Experience & -.38 & .20 & -.19 & -.38 & .19 & -.19 \\
\hline Support & & & & .19 & .06 & $.30^{* *}$ \\
Education & & & & .52 & .24 & $.21^{*}$ \\
Externalising & & & & -.13 & .09 & -.15 \\
Internalising & & & & -.01 & .07 & -.01 \\
\hline$R^{2}$ & & .04 & & & .19 & \\
$F$ for change in $R^{2}$ & & 1.77 & & & $3.72^{* *}$ & \\
\hline
\end{tabular}

Note. ${ }^{\star} p<.05 .{ }^{* *} p<.01$. 


\section{Discussion}

The ability to manage a classroom in a manner that promotes a safe environment and lays the foundation for high levels of learning requires a wide range of skills. Classroom management is a complex component of the teaching process and one that pre-service and in-service teachers alike consistently identify as an area of great concern (Fontaine et al., 2012; Veenman, 1984). Teachers' confidence in their own ability to manage the classroom environment may indicate the strengths and needs of practicing teachers. In the present study, we examined preschool teachers' perceptions of their own competence for managing challenging behaviour within their classrooms. Four findings merit discussion with regard to this investigation. First, it was anticipated that having experience in managing challenging behaviour would be predictive of higher self-perceptions of competency to do so. As age could be argued to provide increased opportunity for interacting with children with challenging behaviour, it was examined in concert with experience. In contrast to our predictions, neither age nor experience were significant in predicting preschool teachers' confidence in the management of challenging behaviour. It should be noted that in the present investigation respondents were queried as to whether or not they had experience with students with challenging behaviour and were not asked to reflect on the quality of that experience. Thus, one explanation for the null finding may be that it takes more than simply experience with challenging behaviour, and instead requires successful experience in managing behaviour in order to boost teacher confidence in this area.

Second, as expected in the present study, preschool teacher's prior education in classroom management was predictive of higher self-assessments of competence in managing challenging behaviour. This finding suggests that regardless of age or experience in dealing with children with challenging behaviour, additional education can have a significant effect on how teachers perceive their own competence. However, it should be noted that in the present study only a small percentage of the preschool teachers responding to this question (6.6\%) reported having any prior coursework in this area. This is not surprising given that in an analysis of the teacher education system in Croatia, Croatian teachers reported that their preparation programmes provided them with low levels of knowledge and skills for initially working with children with emotional and learning difficulties. In addition, pre-service teachers from Croatian universities rated classroom management as one of their lowest areas of preparation (Pavin, Rijavec, \& Miljević-Riđički, 2005). Moreover, our own informal investigation of teacher preparation programmes across Croatia yielded 
evidence of the availability of only a handful of elective and required courses in classroom management in Croatian universities.

Third, it appears that perceptions of one's own competence to address the needs of students with challenging behaviours can be positively influenced by the level of professional support made available to teachers to assist them in dealing with such problems. In the present investigation, the preschool teachers most frequently reported receiving at least some professional support for working with challenging students (i.e., 37\%) while an additional $7 \%$ reported receiving full support from their professional colleagues. While these data suggest that help is available for many teachers in Croatian preschool classrooms, it should be noted that a considerable percentage of preschool teachers either did not perceive the availability of such support or did not, for some reason, access the assistance of these professionals when encountering situations in which support was needed. Specifically, a large percentage reported receiving little (i.e., $24 \%$ ) to no support (i.e., $18 \%$ ) to address the behavioural challenges they face in the classroom. These results are interesting given that the Croatian education system requires the availability of specialists (e.g., psychologist, pedagogue, speech and language therapist, special education teacher, specialist for behaviour issues) to support teachers with implementation of inclusive practices for educating students with disabilities in the general education environment (The State Pedagogical Standard of Preschool Education, 2008). The government requires that these specialists be made available in all schools so that all teachers have access to the necessary support for meeting the needs of students with disabilities, including those with significant behavioural challenges. Despite this legal requirement, previous research also suggests that Croatian teachers may not be getting enough assistance to support inclusive practices. Specifically, Croatian teachers reported that their need for specialist support was much greater than what was available (Skočić Mihić, Beaudoin, \& Krsnik, 2016; Skočić Mihić, 2011; Srok \& Skočić Mihić, 2013). Given that it is common for Croatian universities to focus on theory over application and practice, the problem with accessing support may be that available specialists do not have the necessary background training or expertise to provide a high level of support for dealing with significant behavioural challenges (Kokić, Vukelić, \& Ljubić, 2010). Taken together, the present findings and current practice suggest that training in the application of positive practices for the behaviour management of young children could provide an important addition to syllabi for the preparation of Croatian preschool teachers, as well as for the pre-service training of the educational specialists who support preschool teachers in this work. 
Finally, the frequency of problem behaviours encountered, regardless of their nature (i.e., internalising, externalising), did not appear to influence preschool teachers' perceived competence in behaviour management. Some researchers have reported inconsistent findings regarding the nature of the relation between preschool teachers' perceptions of students' problem behaviours and self-reports of confidence to manage those problem behaviours. For example, Arbuckle and Little (2004) found a significant negative relation between teacher confidence and problem behaviours when teachers rated the problem behaviours of boys in upper primary through lower secondary levels, but not when they considered the problems of girls. As previously mentioned, in the present investigation, we used a newly constructed scale to determine types and frequencies of problem behaviour encountered by teachers in Croatian preschool classrooms. Investigation of the metric characteristics of this measure demonstrated the potential for further exploration using this scale. However, in future research, it would be informative to examine the relations between teacher confidence and problem behaviour according to student gender.

\section{Conclusion}

Research specific to Croatian classrooms, though scant, previously indicated that teachers encountered low levels of problem behaviour in their classrooms. In the present investigation, the overwhelming majority of preschool teachers reported experience in dealing with challenging behaviours. This finding lends support for the need for future research to more closely examine the quantitative and qualitative aspects of Croatian teachers' experiences in dealing with challenging behaviour and teacher knowledge of specific practices that are most likely to positively influence the outcomes of behavioural change for their students. As findings from previous research suggest that examining teachers' experience relative to student gender may yield distinct patterns of results (see, for example, Arbuckle \& Little, 2004), inspection of experience with behaviour according to student gender would be informative. Furthermore, Croatian university pre-service preparation programmes should include more required and elective coursework in the area of classroom management. Time and again, teachers entering the profession have reported a lack of preparation in classroom management as a primary concern and obstacle to professional success (Fontaine, et al., 2012). Yet, the need for preparation for classroom management extends well beyond pre-service training opportunities. As pointed out in the report of the Development of Teacher Education Study Course and Preschool Education Study Course (Vujičić, Čepić, \& Lazzarich, 2010), '[...] from 
a developmental perspective, university preschool teacher education represents only a basic stage upon which, through lifelong learning processes, a preschool teacher's autonomous, personal and professional competences would be developed' (p. 34). Thus, the ongoing development of competency in classroom management through participation in professional development opportunities may provide preschool teachers with critical support for long-term professional growth. In addition, professional collaboration in the work environment can extend learning opportunities to practice settings through the provision of ongoing support for dealing with children with challenging behaviour. Opportunities for obtaining support from professional specialists should be made available to all teachers when they are dealing with students with challenging behaviour, and teachers should be encouraged to access existing resources when needed.

\section{References}

Alvarez, H. K. (2007). The impact of teacher preparation on responses to student aggression in the classroom. Teaching and Teacher Education, 23, 1113-1126.

Arbuckle, C., \& Little, E. (2004). Teachers' perceptions and management of disruptive classroom behavior during the middle years (years five to nine). Australian Journal of Educational \& Developmental Psychology, 4, 59-70. Retrieved from chrome-extension://oemmndcbldboiebfnladdacbdfmadadm/ https://www.newcastle.edu.au/_data/assets/pdf_file/o015/100428/v4-arbuckle-little.pdf Beaudoin, K., Lončarić, D., \& Skočić Mihić, S. (2017). Classroom size and frequency of challenging behaviours in relation to the support that teachers need in managing those behaviours. In L. Vujičić, O. Holz, M. Duh, \& M. Michielsen (Eds.), Contributions to the development of the contemporary paradigm of the institutional childhood (pp. 43-53). Zürich: LIT Verlag.

Beaudoin, K. Skočić Mihić, S., \& Lončarić, D. (2016a). Behaviors of concern to Croatian primary school teachers. Journal of International Special Needs Education, 19(2), 69-80.

Beaudoin, K., Skočić Mihić, S., \& Lončarić, D. (2016b). Frequency of challenging behaviours perceived by Croatian preschool teachers. In N. Tatković, M. Radetić-Paić, \& I. Blažević (Eds.), Kompetencijski pristup kvaliteti ranog i predškolskog odgoja i obrazovanja [Competence approach to quality of early and pre-school education] (pp. 391-40o). Medulin: Dječji vrtić Medulin and Fakultet za odgojne i obrazovne znanosti Sveučilišta Jurja Dobrile u Puli.

Campbell, S. B. (1995). Behavior problems in preschool children: A review of recent research. Journal of Child Psychology and Psychiatry, 36(1), 113-149.

Carlson, J. S., Tiret, H. B., Bender, S. L., \& Benson (2011). The influence of group training in the incredible years teacher classroom management program on preschool teachers' classroom management strategies. Journal of Applied School Psychology, 2(27), 134-154.

Chan, (2008). General, collective, and domain-specific teacher self-efficacy among Chinese prospective 
and in-service teachers in Hong Kong. Teaching and Teacher Education, 24(4), 1057-1069.

Choy, D., Chong, S., Wong, A. G. L., \& Wong, I. Y. F. (2011). Beginning teachers' perceptions of their levels of pedagogical knowledge and skills: Did they change since their graduation from initial teacher preparation? Asia Pacific Education Review, 12(1), 79-98.

Fontaine, S., Kane, R., Duquette, O., \& Savoie-Zajc, L. (2012). New teachers' career intentions: Factors influencing new teachers' decisions to stay or leave the profession. Alberta Journal of Educational Research, 57(4), 379-408.

Friedman-Krauss, A. H., Raver, C. C., Neuspiel, J. M., \& Kinsel, J. (2014). Child behavior problems, teacher executive functions, and teacher stress in Head Start classrooms. Early Education and Development, 25(4), 681-702.

Ingersoll, R. M. (2001). Turnover and teacher shortages: An organizational Analysis. American Educational Research Journal, 38(3), 499-534.

Johansen, A., Little, S. G., \& Akin-Little, A. (2011). An examination of New Zealand teachers' attributions and perceptions of behavior, classroom management, and the level of formal teacher training received in behavior management. Kairaranga, 12(2), 3-12.

Keresteš, G. (2006). Učiteljske procjene problematičnosti i učestalosti emocionalnih teškoća i teškoća u ponašanju kod učenika nižih razreda osnovne škole [Teacher's perceptions of emotional and behavioral difficulties of lower grades elementary school students]. Hrvatska revija za rehabilitacijska istraživanja, 42(1), 3-15.

Kokić, I. B., Vukelić, A., \& Ljubić, M. (2010). Mapping policies and practices for the preparation of teachers for inclusive education in contexts of social and cultural diversity. European Training Foundation. Country Report for Croatia. EU: European Training Foundation. Retrieved from http:// www.etf.europa.eu/webatt.nsf/o/C12578310056925BC125772E002BD5AB/\$file/NOTE85SBD6.pdf

Kotaman, H. (2010). Turkish early child educators' sense of teacher efficacy. Electronic Journal of Research in Educational Psychology, 8(2), 603-616.

Lavigne, J. V., Gibbons, R. D., Christoffel, K. K., Arend, R., Rosenbaum, D., \& Binns, H. et al. (1996). Prevalence rates and correlates of psychiatric disorders among preschool children. Journal of the American Academy of Child and Adolescent Psychiatry, 35(2), 204-214.

Martin, A. J., Linfoot, K., \& Stephenson, J. (1999). How teachers respond to concerns about misbehavior in their classroom. Psychology in the Schools, 36(4), 347-358.

Marzano, R. J., \& Toth, M. D. (2013). Teacher evaluation that makes a difference: A new model for teacher growth and student achievement. Alexandria, VA: Association for Supervision and Curriculum Development.

Melnick, S. A., \& Meister, D. G. (2008). A comparison of beginning and experienced teachers' concerns. Educational Research Quarterly, 31(3), 39-56.

Qu, C. H., \& Kaiser, A. P. (2003). Behavior problems of preschool children from low-income families: Review of the literature. Topics in Early Childhood Special Education, 23(4), 188-216.

Pavin, T., Rijavec, M, \& Miljević-Riđički, R. (2005). Prikaz rezultata empirijskih istraživanja na glavnim sudionicima sustava obrazovanja učitelja i nastavnika [Delivering results of empirical research on the 
main participants of the teacher education system for elementary school and high school teachers]. In V. Vizek Vidović (Ed.), Cjeloživotno obrazovanje učitelja i nastavnika: višestruke perspektive (pp. 92-124). Zagreb: Institut za društvena istraživanja u Zagrebu.

Range, B. G., Duncan, H. E., Scherz, S. D., \& Haines, C. A. (2012). School leaders' perceptions about incompetent teachers: Implications for supervision and evaluation, NASSP Bulletin, 96(4), 302-322. Sak, R., Sahin Sak, I. T., \& Yerlikaya, I. (2015). Behavior management strategies: Beliefs and practices of male and female early childhood teachers. European Early Childhood Education Research Journal, 23(3), 328-339.

Shernoff, E. S., \& Kratochwill, T. R. (2007). Transporting an evidence-based classroom management program for preschoolers with disruptive behavior problems to a school: An analysis of implementation, outcomes, and contextual variables. School Psychology Quarterly, 22(3), 449-472.

Skočić Mihić, S. (2011). Spremnost odgajatelja i faktori podrške za uspješno uključivanje djece s teškoćama u rani i predškolski odgoj i obrazovanje [The readiness of preschool teacher and support factors for successful preschool inclusion]. Unpublished doctoral dissertation. Faculty of Education Rehabilitation Sciences, University of Zagreb, Zagreb.

Skočić Mihić, S., Beaudoin, K., \& Krsnik, M. (2016). Mišljenje odgojitelja o individualiziranom odgojno-obrazovnim programima [Preschool teachers' opinions about individualized education plan]. In V. Mlinarević, T. Vonta, \& T. Borovac (Eds.), Rani i predškolski odgoj i obrazovanje - izazovi i perspective (pp. 77 - 86). Osijek: Grafika.

Srok, N., \& Skočić Mihić, S. (2013). Odgajatelji i stručni suradnici u savjetodavnoj ulozi [Consulting role of preschool teachers and specialists]. Dijete, vrtić, obitelj, 70, 19-21.

Stephenson, J. Linfoot, K., \& Martin, A. (2000). Behaviours of concern to teachers in the early years of school. International Journal of Disability, Development and Education, 47(3), 225-235.

Stough, L. (2006). The place of classroom management and standards in teacher education. In C. M. Evertson \& C. S. Weinstein (Eds.), Handbook of classroom management: Research, practice, and contemporary issues (pp. 909-924). Mahwah, NJ: Lawrence Earlbaum Associates.

The state pedagogical standard of preschool education (2008). Narodne novine [Official Gazette], Croatia, No. 63/08.

Torff, B., \& Sessions, D. N. (2005). Principals' perceptions of the causes of teacher ineffectiveness. Journal of Educational Psychology, 97(4), 530-537.

Veenman, S. (1984). Perceived problems of beginning teachers. Review of Educational Research, 54(2), $143^{-178 .}$

Vidić, T. (2010). Učiteljske percepcije učeničkih ponašanja: (Ne)poštivanje, socijalizacija i pozornost na satu [Teachers' perception of students' behavior: (Dis)respect, socialization, and attentiveness]. Život $i$ škola, 23(56), 77-90.

Vujičić, L., Čepić, R., \& Lazzarich, M. (2010). Scientific Contribution from 1998 to 2010. Rijeka: Faculty of Teacher Education University of Rijeka.

Wang, M. C., Haertel, G. D., \& Walberg, H. J. (1994). What helps students learn? Educational Leadership, 51(4), 74-79. 
Webster-Stratton, C. (2006). The incredible years: Teacher training program. Seattle, WA: The Incredible Years.

West, J., Denton, K., \& Germino-Hausken, E. (2000). America's kindergartners: Findings from the early childhood longitudinal study, Kindergarten Class of 1998-99, Fall 1998. NCES 2000-070. Washington, DC: National Center for Education Statistics.

Wong, A. F. L., Chong, S., \& Choy, D. (2012). Investigating changes in pedagogical knowledge and skills from pre-service to the initial year of teaching. Educational Research for Policy and Practice, 11(2), 105-117.

Wubbels, T. (2011). An international prospective on classroom management: What should prospective teachers learn? Teaching Education, 22(2), 113-131.

\section{Biographical note}

KATHLEen BeAUdoin, $\mathrm{PhD}$, is an associate professor at University of Washington Tacoma where her research and teaching interests focus on supporting educators to work with students with challenging behaviours. She was a Fulbright Scholar at University of Rijeka, Croatia in 2010 and continues her work with colleagues from Rijeka in the present study.

SANJA Sкос̌ıć Minić, PhD, is an assistant professor at the Faculty of Teacher Education University of Rijeka where she is teaching courses related to inclusive education and counselling. Her academic and scientific interests are focused on the teachers' competences for inclusive teaching, parental support and facilitation of inclusive values.

DARKo LončArić, $\mathrm{PhD}$, is an Associate professor at the University of Rijeka, where he is teaching graduate and postgraduate study courses related to educational psychology, developmental psychology, and applied multivariate statistics. He received a PhD in Psychology in 2008 at University of Ljubljana, Slovenia. 